\title{
EFFECT OF ORGANIC AND INORGANIC FERTILIZATION ON AVAILABILITY OF SOME NUTRIENTS AND SOIL ORGANIC MATTER QUALITY AFTER WHEAT AND CORN CROP ROTATION \\ Hamoud, H.S. \\ Soils, Water and Environment Research Institute, ARC, Egypt.
}

\begin{abstract}
Two field studies were conducted at the experimental farm of Sakha Agric. Res. Station to evaluate the impact of composted rice straw, town refuse and their mixture with urea on the availability of NPK nutrients and some soil organic matter fraction and its quality after wheat (Sakha 94) followed by corn (Giza 352) cropping sequence. The obtained results showed that the tested soil characteristics were affected due to the applied composts as follows:

1. The obtained results gave significant increases in $N, P$ and $K$ availability under wheat and corn plant but the application of composted rice straw was more effective for increasing available N, P and $\mathrm{K}$ in soil in the $2^{\text {nd }}$ season (after corn), while composted town refuse given an opposite trend.

2. Light fraction, microbial biomass carbon and polysaccharides increased with increasing application rates especially in the $1^{\text {st }}$ season (after wheat).

3. The obtained data show that, raise of application rate of composted material $\left(T_{4} \&\right.$ $\mathrm{T}_{7}$ ) increased the total carbon (OC\%), the percent of humic acid carbon $\left(\mathrm{C}_{\mathrm{HA}}\right)$ and fulvic acid carbon (CFA) of the total carbon. However, there was significant changes in $\mathrm{C}_{\mathrm{HA}} / \mathrm{C}_{\mathrm{FA}}$ and $\mathrm{C}_{\mathrm{HA}}+\mathrm{C}_{\mathrm{FA}}$ /humin carbon ( $\mathrm{C}_{\text {hum }}$ ) ratio but decreased the percent of Chum of the total carbon especially in the $2^{\text {nd }}$ season. On the other hand, there was no significant changes in $\mathrm{E}_{4} / \mathrm{E}_{6}$ ratios.

4. The total acidity and functional groups of obtained humic acid was increased with
\end{abstract} increasing application rate.

\section{INTRODUCTION}

The continued depletion of soil organic matter (SOM), resulting from agricultural production, has been identified as critical problem in most soils throughout the world (Pulleman et al., 2000).

The content and quality of SOM are the most important factors maintaining the quality and fertility soils (Stevenson, 1994 and Reeves, 1997). Therefore, there is a need to develop strategies, besides the use of crop residues, to assure the return of the organic matter (OM) that is gradually consumed and oxidized in cultivated areas. Land application of organic wastes and biosolids produced in high quantity from diverse human activities can, at least partially, solve this problem (Etana et al, 1999 and Reeves, 1997). These wastes range from simple domestic wastes to complex industrial wastes (Chirenje and Ma, 2002). Application of these wastes to agriculture land directly improves soil properties such as: structure, water retention capacity, buffering capacity, nutrient status, in addition to the indirect effects on different microbial populations (Reeves, 1997). In addition, many researches have reported the beneficial effects of compost 
incorporation on soil properties such as: water retention, cation exchange capacity, soil structure and SOM quality (Balesdent et al., 2002 and Etana et al., 1999).

However, land application has some risks as it involves the use of watr that can contain high levels of toxic constituents. For example, there may be greater risk of heavy metals entering the food chain via plant uptake $\mathrm{Wu}$, 2001) and excess supply of $P, K$ and nitrates.

The quality of the OM may determine its beneficial effects.

Quality in these cases is defined in terms of the reactive component of OM (Important for nutrient supply and storage) and its physical qualities (critical for water retention and improvement of other soil physical properties). One way of improving the quality of applied wastes is composting which yields an excellent product due to the accumulation of humus like substances produced from biochemical processes that take place during composting. Thus, the application of composted materials to soils is expected to increase both the quantity and quality of SOM.

In general, the mean of SOM components are humic acid $(\mathrm{HA})$, fulvic acid (FA) and humin, which are quantified based on their solubility in alkaline and acid solutions (Stevenson, 1994). The quality of SOM can be evaluated by determining the $\mathrm{C}_{\mathrm{HA}} / \mathrm{C}_{\mathrm{FA}}$ and $\mathrm{E}_{4} / \mathrm{E}_{6}$ ratios and for through the classification of $\mathrm{HA}$. The $\mathrm{C}_{\mathrm{HA}} / \mathrm{C}_{\mathrm{FA}}$ ratio is defined as the carbon ratio between the HA and FA present in the SOM. The $\mathrm{C}_{\mathrm{HA}} / \mathrm{C}_{\mathrm{FA}}$ ratio has been used as an index describing the intensity of humification process (Stevenson, 1994). While the value $E_{4} / E_{6}$ ratio is used to characterize $H A$ and $F A$. It is indicative of the molecular size or chemical complexity degree of both HA and FA. Values from 1 to 5 are correlated with more aromatic condensation (Kononova, 1966).

Characterization of HA molecules such as functional groups, elemental composition and the degree of humification indicates clearly the quality of SOM (Kumada, 1987).

The main purpose of this study was to evaluate the effects of dressing organic amendments from different sources (composted rice straw and composted town refuse) on availability of NPK, SOM biochemical properties and the quality of SOM, specifically HA and FA under two crops (wheat and corn).

\section{MATERIALS AND METHODS}

A field experiment have been carried out at the experimental farm of Sakha Agric. Res. Station during the winter season of 2008 routed by the summer season of 2009.

Wheat, Triticum aestivum L. Sakha 94 was planted at November 2008 and followed by corn, Zea mays L. Giza 352 cultivated at May 2009 in the same experimental area. Some chemical properties of the experimental soil are shown in Table (1).

Rice straw and town refuse and their mixture were added to soil or in combination with mineral fertilizer. The composted materials were mixed with 
soil surface $(0-15 \mathrm{~cm})$ before wheat sowing as one dose. The same experimental area was planted with corn without any additions of composted materials. Each treatment was replicated 4 times in completely block randomized design. Some characteristics of these composted materials are presented in Table (2).

Table (1): Some chemical properties of the tested soil.

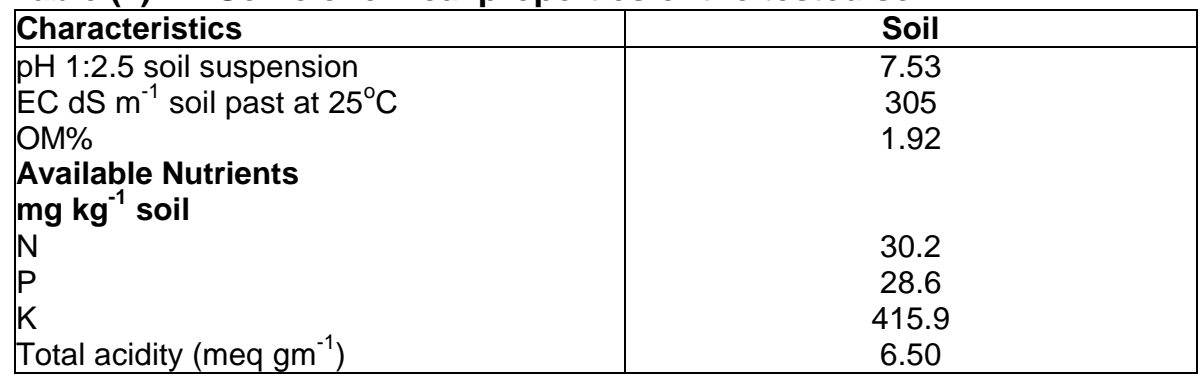

Table (2): Some characteristics of rice straw and town refuse composts after maturing

\begin{tabular}{|l|c|c|}
\hline Characteristics & Rice straw compost & Town refuse compost \\
\hline EC $1: 1 \mathrm{dS} \mathrm{m}^{-1}$ & 1.19 & 3.69 \\
$\mathrm{pH}(1: 10)$ & 7.23 & 7.75 \\
Bulk density gm/cm ${ }^{3}$ & 0.50 & 0.52 \\
Moisture content \% & 39 & 43.0 \\
Organic carbon \% & 25.49 & 16.83 \\
Organic matter \% & 43.84 & 28.95 \\
Total N\% & 1.25 & 0.98 \\
C/N ratio & 20.40 & 17.17 \\
$\mathrm{E}_{4} / \mathrm{E}_{6}$ & 3.78 & 5.23 \\
$\mathrm{C}_{\mathrm{HA}} \%$ & 39.73 & 35.82 \\
$\mathrm{C}_{\mathrm{FA}} \%$ & 20.91 & 19.53 \\
$\mathrm{C}_{\mathrm{H} \text { humin } \%}$ & 39.36 & 44.65 \\
$\mathrm{C}_{\mathrm{HA}} / \mathrm{C}_{\mathrm{FA}}$ & 1.90 & 1.83 \\
\hline
\end{tabular}

The treatment of experimental soil area are shown in Table (3). All treatments were fertilized with superphosphate, $15 \mathrm{~kg} \mathrm{P}_{2} \mathrm{O}_{5} \mathrm{fed}^{-1}$.), potassium sulphate $\left(24 \mathrm{~kg} \mathrm{~K}_{2} \mathrm{O} \mathrm{fed}{ }^{-1}\right.$.) and urea $\left(15 \mathrm{~kg} \mathrm{~N}^{-1} \mathrm{fed}^{-1}\right.$.) before sowing of both wheat and corn. The collected soil samples $(0-15 \mathrm{~cm})$ after wheat and corn harvesting prepared for chemical analysis. Chemical standard methods (Jackson, 1973 and Page et al., 1982)

Table (3): Experimental treatment

\begin{tabular}{|c|c|}
\hline Treat. No. & Tested treatment \\
\hline $\mathrm{T}_{1}$ & Control (without addition) \\
\hline $\mathrm{T}_{2}$ & Dressing $60 \mathrm{~kg}$ urea- $\mathrm{N}$ fed $^{-1}$ in two equal doses \\
\hline$T_{3}$ & Addition of 30 ton $^{-1} d^{-1}$ rice straw compost \\
\hline $\mathrm{T}_{4}$ & 30 ton fed ${ }^{-1}$ rice straw compost and $60 \mathrm{~kg}$ urea $\mathrm{N}$ fed ${ }^{-1}$. \\
\hline $\mathrm{T}_{5}$ & 15 ton fed $^{-1}$ rice straw compost and $30 \mathrm{~kg}$ urea $\mathrm{N}$ fed ${ }^{-1}$. \\
\hline $\mathrm{T}_{6}$ & 30 ton fed $^{-1}$ town refuse compost addition \\
\hline $\mathrm{T}_{7}$ & 30 ton fed $^{-1}$ town refuse compost and $60 \mathrm{~kg}$ urea $\mathrm{N} \mathrm{fed}^{-1}$ \\
\hline $\mathrm{T}_{8}$ & 15 ton fed ${ }^{-1}$ town refuse compost and $30 \mathrm{~kg}$ urea $\mathrm{N} \mathrm{fed}^{-1}$ \\
\hline
\end{tabular}


SOM characterization:

Light fraction organic matter (LF) $\mathrm{mg} \mathrm{kg}^{-1}$ soil:

The light fraction was isolated using a modification of the method described by Strickland and Sollins (1987).

Soil microbial biomass carbon (MBC) $\mu \mathrm{g} \mathrm{gm-1}$ soil:

Soil microbial biomass was determined after wheat and corn harvesting using the rapid, classical chloroform fumigation-direct extraction method, as reported by El-Kammah (2000).

Total polysacchrides in soil $\mu$ moles glucose $\mathrm{g}-1$ soil:

Total polysaccharides was measured according to Lowe (1993) as described in detail by Abdel-Kader (1998).

Extraction and purification of humic acids:

Isolation and purification of humic and fulvic acid (HA and FA) were performed as described by Posner (1966), and Stevenson (1994). The soil samples were treated with a mixture of $0.1 \mathrm{M}$ sodium pyrophosphate $+0.1 \mathrm{M}$ sodium hydroxide. The supernatant were collected and acidified to $\mathrm{pH} 2$ with concentrated $\mathrm{H}_{2} \mathrm{SO}_{4}$ and allowed to stand for $24 \mathrm{hr}$. The coagulated $\mathrm{HA}$ was separated by centrifugation and freeze-dried. In order to reduce the ash content of the purified humic acids, the dried humic acid fractions were shaken with $100 \mathrm{ml}$ of Khan's mixture $(0.5 \mathrm{ml}$ conc. $\mathrm{HCl}+0.5 \mathrm{ml} \mathrm{HF} 48 \%+$ $99 \mathrm{ml} \mathrm{H}_{2} \mathrm{O}$ ) for $24 \mathrm{hr}$ (Schnitzer and Khan, 1978). The acid mixture was centrifuged and the humic acid gels were dialyzed against deionized water until free of $\mathrm{Cl}^{-}$and then dried as mentioned above. The percent of carbon humic acid $\left(\mathrm{C}_{\mathrm{HA}}\right)$ and fulvic acid $\left(\mathrm{C}_{\mathrm{FA}}\right)$ of the total organic carbon $(\mathrm{OC})$ were determined according to the rapid method described by Walkely Black. Optical density $E_{4} / E_{6}$ humic acids was measured spectro-photometrically at 465 and $665 \mathrm{~nm}$ (Kononova, 1966).

Proportions of humic acid and fulvic acid carbon contents relative to the total carbon $(\mathrm{OC})$ were calculated; $\mathrm{C}_{\mathrm{HA}} / \mathrm{C}_{\mathrm{FA}}$ and $\mathrm{C}_{\mathrm{HA}}+\mathrm{C}_{\mathrm{FA}} /$ Chum respectively.

Total acidity and carboxylic functional groups of the humic acids were determined by the $\mathrm{Ba}(\mathrm{OH})_{2}$ and $\mathrm{Ca}\left(\mathrm{CH}_{3}-\mathrm{COO}\right)_{2}$ methods, respectively (Schnitzer and Khan, 1972). Phenolic hydroxyls were obtained by difference.

Statistical analysis of data was done according to Snedecor and Cochran (1967).

\section{RESULTS AND DISCUSSION}

\section{Effect of composts application on the availability of NPK:}

Data in Table (4) show that the application of composted material had a significant effect on the availability of $\mathrm{N}, \mathrm{P}$ and $\mathrm{K}$. Available N, P and K content in soil were increased up to 84.8484 .00 and $660.90 \mathrm{mg} / \mathrm{kg}$ for treatment $T_{7}, T_{6}, T_{4}$, respectively after wheat crop and up to $97.64 \& 92.52$ and $720.82 \mathrm{mg} / \mathrm{kg}$ for treatment No. 4 for $\mathrm{N}$ and $\mathrm{P}$ and $\mathrm{T}_{3}$ for $\mathrm{K}$, respectively after corn crop. The application of composted rice straw was more effective for increasing available nutrients in soil in the $2^{\text {nd }}$ season, this may be due to its chemical composition. These highly levels were interpreted by many 
others, Metwally and Khamis (1998) stated that organic maturing plays role in increasing the $\mathrm{N}$ availability through microorganism activities, beside decreasing $N$ losses by leaching and volatilization. The increase in the soluble $\mathrm{P}$ from addition of compost can be described as resulting from phophohumic complexes that minimize immobilization process, anion replacement of phosphate by humic ions and coating of sesquioxide particles by humus to form a cover which reduces the phosphate fixating capacity of the soil (Rechcigl, 1995). In addition, the increasing of available $\mathrm{K}$ after addition of compost are supported by Tan (1993) who found that the humic and fulvic acids are capable for dissolving very small amounts of potassium from the soil minerals by chelating, complex reaction or both released amounts of $\mathrm{K}$ beings increased with time.

Table (4): Effect of application composted rice straw and town refuse on available nutrients in the soil after wheat and corn harvesting.

\begin{tabular}{|c|c|c|c|c|c|c|}
\hline \multirow{3}{*}{ Treatment } & \multicolumn{6}{|c|}{ Available nutrients (mg/kg soi) } \\
\hline & \multicolumn{3}{|c|}{ After wheat } & \multicolumn{3}{|c|}{ After corn } \\
\hline & $\mathbf{N}$ & $\mathbf{P}$ & $\mathbf{K}$ & $\mathbf{N}$ & $\mathbf{P}$ & $\mathbf{K}$ \\
\hline $\mathrm{T}_{1}$ & $30.50 \mathrm{~d}$ & $28.33 \mathrm{e}$ & $417.90 \mathrm{c}$ & $33.92 \mathrm{~d}$ & $30.42 \mathrm{f}$ & $420.11 d$ \\
\hline $\mathrm{T}_{2}$ & $52.92 \mathrm{~d}$ & $30.24 \mathrm{e}$ & $483.80 \mathrm{c}$ & $57.22 \mathrm{~d}$ & $42.94 \mathrm{f}$ & $495.20 \mathrm{~d}$ \\
\hline $\mathrm{T}_{3}$ & $44.31 \mathrm{a}$ & $72.37 \mathrm{~b}$ & $596.36 \mathrm{c}$ & $69.13 \mathrm{c}$ & $79.33 b$ & $720.82 \mathrm{a}$ \\
\hline $\mathrm{T}_{4}$ & $79.38 \mathrm{a}$ & $74.24 \mathrm{~b}$ & $660.90 \mathrm{a}$ & $97.64 \mathrm{c}$ & $92.52 \mathrm{a}$ & $696.20 \mathrm{a}$ \\
\hline $\mathrm{T}_{5}$ & $72.03 \mathrm{~b}$ & $54.60 \mathrm{~d}$ & $544.88 b$ & $78.36 \mathrm{~b}$ & $66.30 \mathrm{c}$ & $630.41 \mathrm{~b}$ \\
\hline $\mathrm{T}_{6}$ & $63.06 \mathrm{a}$ & $84.00 \mathrm{a}$ & $654.90 \mathrm{a}$ & $58.37 \mathrm{~d}$ & $79.88 b$ & $599.30 \mathrm{c}$ \\
\hline $\mathrm{T}_{7}$ & $84.84 \mathrm{a}$ & $67.20 \mathrm{c}$ & $655.20 \mathrm{a}$ & $78.09 \mathrm{~b}$ & $58.39 \mathrm{~d}$ & $585.13 \mathrm{C}$ \\
\hline $\mathrm{T}_{8}$ & $66.28 \mathrm{c}$ & $53.76 \mathrm{~d}$ & $547.80 \mathrm{a}$ & $59.32 \mathrm{~d}$ & $49.20 \mathrm{e}$ & $518.22 d$ \\
\hline L.S.D. 5\% & 4.10 & 2.66 & 30.63 & 3.20 & 3.37 & 39.22 \\
\hline L.S.D. $1 \%$ & 5.60 & 3.67 & 41.42 & 4.35 & 4.60 & 53.44 \\
\hline
\end{tabular}

In the same column, means followed by the same letter are not significantly different at $5 \%$ level according to Duncan multiple range test

2. Effect of composted and mineral fertilizer on LF, MBC and polysaccharides of the tested soil after harvesting of wheat and corn crops:

A. Light fraction (LF) $\mathrm{mg} \mathrm{kg}^{-1}$ soil:

Light fraction (LF) material "active fraction" plays a prominent role in soil nutrient dynamics. This fraction, expressed largely status of organic residues in various stages decomposition, has a high concentration of organic $\mathrm{C}$ and $\mathrm{N}$ relative to that of the whole organic matter (Theodorou, 1999).

Regarding to the LF component as affected by composted type and rates of both organic and mineral fertilizers data in Table (5) clear that the LF increased with increasing of addition rates of composted materials in combination with mineral $\mathrm{N}$ fertilizer up to $18.47,20.25$ and 19.67 for treatment $T_{4}, T_{7}$ and $T_{8}$, respectively after wheat crop. In addition under the second crop, the results showed the same trend. It is worthy to indicate that LF is the most liable active organic compound and significantly affected the soil biological, chemical, physical as well as nutrient status of agricultural soils (Stevenson, 1994). 
B. Soil microbial biomass carbon (MBC) $\mu \mathrm{g} \mathrm{g}^{-1}$ soil:

Soil microbial carbon is considered a transformation agent of soil organic materials and a labile reservoir of nutrients such as $\mathrm{N}, \mathrm{P}$ and $\mathrm{S}$. It has been used as one of parameters to estimate the microbial growth (Jenkinson and Ladd, 1981). Data in Table (5) show that, using composts materials as a source of organic amendments generally increased soil microbial biomass $C$ compared with control in both crops. Whereas, the highest values of soil microbial biomass were obtained in treatment No. 4 and 7 after the two seasons. It may be due to the increase in soil microbiological process to the larger amount of organic matter in composts. These results are in harmony with those obtained by El-Sayed (2005).

\section{c. Total and labile polysaccharides ( $\mu$ moles glucose $\mathrm{g}^{-1}$ soil)}

Data in Table (5) reveal that the different applications of both composts significantly increased total and labile saccharides in soil compared to the control after the two crops. These results are in confirm with those obtained by Gomah and El-Essawi (1975), Abd El-Kader (1998) and El-Sayed (2005)

3. Effect of compost type and mineral nitrogen application on humic substances, carbon fractions after harvesting of wheat and corn crops:

3.1. Group composition of carbon humic substances:

A. The distribution of the three major humus (HA, FA and Humin) components as affected by addition of composts types are presented in Table (6).

Obtained data show that the expect after the two crops the treatment number $T_{4}$ and $T_{7}$ after wheat crop and $T_{3}$ and $T_{4}$ after corn crop. However, the humic acids carbon predominant over the fulvic acids in all treatments of the studied soil it may be due to the high rate of composts addition and the increase of the activity of soil organisms and the soil showed the increase in the degree of humification (Stevenson, 1994).

For the $\mathrm{C}_{\mathrm{HA}} / \mathrm{C}_{\mathrm{FA}}$ ratio, it was increased with increasing rate of addition for the composts and after the two crops. It ranged between 1.38 to 1.69 after wheat crop and 1.27 to 1.53 after corn crop.

The data in Table (6) also show the distribution of the non-hydrolyzable residues or humins (Chum). Data appeared that all studied treatment Chum content generally, is inversely proportional to humic acids and the greater amounts of $\mathrm{OC}$ were found in the humins. The humins was the predominate group of humic substances after the two crops. This may be attributed to the non-hydrolization properties and the stable formation of humins. Also, humins was strongly bound with the mineral part of the soil. These results are in agreement with those obtained by Shalaby et al. (1989). and Oyonarte (1994). To classify the soil under investigation adopting the criteria of Calderon (1982) using his graduation and using only the fractional composition of humus as $\left(\mathrm{C}_{\mathrm{HA}}+\mathrm{C}_{\mathrm{FA}}\right) /$ Chum ratio of the two upper Hum). In this type the $\left(\mathrm{C}_{\mathrm{HA}}+\mathrm{C}_{\mathrm{FA}}\right)$ /Chum ratio is $<1.2$ and the $\mathrm{C}_{\mathrm{HA}} / \mathrm{C}_{\mathrm{FA}}$ ratio is $<2.0$. But in this soil, all treatments less than 1.2 except the treatment No. $T_{3} \& T_{4}$ for $\mathrm{C}_{\mathrm{HA}}+\mathrm{C}_{\mathrm{FA}} /$ Chum for wheat crop and treatment No. $\mathrm{T}_{4} \& \mathrm{~T}_{6}$ for corn crop. 
J. Soil Sciences and Agric. Engineering, Mansoura Univ., Vol.1 (5),May, 2010

$5-6$

459 
B. The ratio of optical densities at 465 and 665 um i.e. $\left(E_{4} / E_{6}\right)$ :

The $\mathrm{E} 4 / \mathrm{E} 6$ ratio is widely used for characterization of humic substances. It is usually decreases with increasing molecular weight and condensation and believed to serve as an index of humification (Stevenson, 1982). According to the data in table (6), it could be noticed that the values of $E_{4} / E_{6}$ for humic substances was decreased with increasing the rate of addition $\left(T_{4}\right.$ $\& T_{7}$ treatment) 3.45 and 3.39 after wheat crop and $3.42 \& 3.35$ after corn crop.

3.2. Total acidity and functional groups analysis of humic acid after wheat and corn harvesting:

Carboxylic and phenolic hydroxyl groups are two major oxygen-containing functional groups in humic materials, as the exchange capacity is due mainly to their dissociation (Schnitzer and Khan, 1972). Data in Table (7) show that total acidity increased with increasing the addition rates of composted material where in treatment No. 4 (7 8.12 and $9.48 \mathrm{meq} \mathrm{g}^{-1}$ after wheat crop and 8.68 and $8.94 \mathrm{meq} \mathrm{g}^{-1}$ after corn crop). On the other hand, carboxylic and phenolic hydroxyl groups have the same trend. These results confirmed with those obtained by Schnitzer (1977) who found that functional group contents of humic acids ranged from 3.9 to $5.2 \mathrm{meq} \mathrm{g}^{-1}$ and from 2.1 to $3.0 \mathrm{meq} \mathrm{g}^{-1}$ carboxyl and phenolic $\mathrm{OH}$ groups, respectively.

Table (7):Effect of composts application on the acidic functional groups of the isolated soil humic substance after wheat and corn harvesting

\begin{tabular}{|c|c|c|c|c|c|c|}
\hline \multirow[t]{2}{*}{ Treatment } & \multicolumn{3}{|c|}{ Wheat } & \multicolumn{3}{|c|}{ Corn } \\
\hline & $\begin{array}{c}\text { Total } \\
\text { acidity } \\
\text { meq g }^{-1}\end{array}$ & $\begin{array}{c}\text { COOH } \\
\text { group } \\
\text { meq } \mathrm{g}^{-1}\end{array}$ & $\begin{array}{l}\text { Phenolic } \\
\text { group } \\
\text { meq g }^{-1}\end{array}$ & $\begin{array}{c}\text { Total } \\
\text { acidity } \\
\text { meq g }^{-1}\end{array}$ & $\begin{array}{c}\mathrm{COOH} \\
\text { group } \\
\text { meq g }^{-1}\end{array}$ & $\begin{array}{l}\text { Phenolic } \\
\text { group } \\
\text { meq g }^{-1}\end{array}$ \\
\hline $\mathrm{T}_{1}$ & $6.53 \mathrm{~d}$ & $4.35 \mathrm{c}$ & $2.18 d$ & $6.59 \mathrm{~b}$ & $4.54 \mathrm{~b}$ & $2.05 \mathrm{c}$ \\
\hline $\mathrm{T}_{2}$ & $6.77 \mathrm{~cd}$ & $4.51 \mathrm{bc}$ & $2.26 \mathrm{~cd}$ & $6.84 \mathrm{~b}$ & $4.56 \mathrm{~b}$ & $2.28 \mathrm{~b}$ \\
\hline $\mathrm{T}_{3}$ & $7.09 \mathrm{~cd}$ & $4.73 \mathrm{bc}$ & $2.36 \mathrm{~cd}$ & $7.15 b$ & $4.79 b$ & $2.41 \mathrm{~b}$ \\
\hline $\mathrm{T}_{4}$ & $8.12 b$ & $5.41 \mathrm{abc}$ & $2.71 \mathrm{~b}$ & $8.68 \mathrm{a}$ & $5.79 \mathrm{a}$ & $2.89 a$ \\
\hline $\mathrm{T}_{5}$ & $7.42 \mathrm{c}$ & $4.95 \mathrm{bc}$ & $2.47 \mathrm{c}$ & $7.32 \mathrm{~b}$ & $4.88 \mathrm{~b}$ & $2.44 \mathrm{~b}$ \\
\hline $\mathrm{T}_{6}$ & $6.98 \mathrm{~cd}$ & $5.65 \mathrm{ab}$ & $2.33 \mathrm{~cd}$ & $7.08 \mathrm{~b}$ & $4.72 \mathrm{~b}$ & $2.36 \mathrm{~b}$ \\
\hline $\mathrm{T}_{7}$ & $9.48 \mathrm{a}$ & $6.32 \mathrm{a}$ & $3.16 \mathrm{a}$ & $8.94 \mathrm{a}$ & $5.96 \mathrm{a}$ & $2.98 \mathrm{a}$ \\
\hline $\mathrm{T}_{8}$ & $7.13 \mathrm{~cd}$ & $4.75 \mathrm{bc}$ & $2.38 \mathrm{~cd}$ & $7.22 \mathrm{~b}$ & $4.81 \mathrm{~b}$ & $2.41 \mathrm{~b}$ \\
\hline L.S.D. 5\% & 0.649 & 1.146 & 0.218 & 0.675 & 0.395 & 0.216 \\
\hline L.S.D. $1 \%$ & 0.894 & 1.579 & 0.300 & 0.930 & 0.545 & 0.297 \\
\hline
\end{tabular}

In the same column, means followed by the same letter are not significantly different at $5 \%$ level according to Duncan multiple range test

\section{REFERENCES}

Abd El-Kader, N.I.J. (1998). Effect of different composted materials on some soil characteristics and biomass of barley crop under salt affected soils. M.Sc. Thesis, Fac. Agric., Tanta Univ.

Blesdent, J.; Cheu, C. and Balaane, M. (2000). Relationship of soil organic matter dynamic to physical protection and tillage. Soil Tillage Res., 52: 215-230. 
Chirenje, T.; Ma, L.Q. (2002). Impact of high volume wood-fired boiler ash amendment on soil properties and nutrient status. Comm. Soil Sci. Plant Anal. 33(1-2): 1-18.

El-Kammah, M.A. (2000). Investigation of amidohydrolases activity in some Egyptian soil inside the plastic tunnels. DB G-SSA Kongress Von 1822 September 2000, Osnobruck, Germany. Mitteilng. Dtsch. Bodenkundl. Gesellsch. 93: 240-243.

El-Sayed, N.A.A. (2005). The impact of irrigation with treated wastewater effluent on soil bio-physicochemical properties and on growth and heavy metals content of some dodder trees grown on calcareous soil. Ph.D. Thesis. Fac. Agric., Tanta, Tanta Univ.

Etana, A.; Hakanson, I.; Swain, E. and Bucas, S. (1999). Effects of tillage depth on organic cool content and physical properties in four Swedish soils. Soil Tillage Res. 52: 129-139.

Calderon, J.U. (1982). Content and composition of humus in arid alluvial soil of Peru. Sov. Soil Sci., 41(5): 47-53.

Gomah, A.M. and El-Essawi T.M. (1975). A study on the role of organic material in stabilizing soil aggregates. Alex. J. Agric. Res., 23(3): 631642.

Jackson, M.L. (1973). Soil Chemical Analysis. Prentice Hall Inc., N.J.

Jenkinson, D.S. and Ladd J.N. (1981). Microbial Biomass in Soil: Measurement and turnover. In E.A. Paul and J.N. Ladd (Ed.). Soil Biochemistry. Vol. 5, Marcel Dekker, New York.

Kononova, M.M. (1966). Soil Organic Matter. Pargamon Press, Oxford

Kumada, K. (1987). Chemistry of soil organic matter. Japan Scientific Societies Press, Elsevier, Tokyo, 241, pp.

Lowe, L.F. (1993). Total and labile polysaccharide analysis of soils. In Carter, M.R. (Ed.). Soil Sampling and Methods of Analysis. Canadian Soc. of Soil Sci. Lewis Publishers, London and Tokyo.

Metwally, Sh.M. and Khamis, M.A. (1998). Comparative effects of organic and inorganic nitrogen sources applied to a sandy soil on availability of $\mathrm{N}$ and wheat yield. Egypt. J. Soil Sci., 38: 35-54.

Oyonarte, C. (1994). Factors affecting soil organic matter turnover in a Mediterranean ecosystems from Sierra De Gador (Spain) : An analytical approach. Commun. Soil Sci., Plant Anal., 25(11-12): 1929-1945.

Page, A.L.; Miller, R.H. and Keeney, D.R. (1982). Methods of Soil Analysis. Amer. Soc. Agron. Inc. Publisher, Madison, Wisconsin.

Posner, A.M. (1966). The humic acid extracted by various reagents from a soil part 1, yield in organic components and titration curves. J. Soil Sci., 17: 65-78.

Pulleman, M.M.; Bouma, J.; Essen, E.A. and Meijles, E.W. (2000). Soil organic matter content as a function of different land uses history. Soil Sci. Soc. Am. J. 64: 689-693.

Rechcigl, J.E. (1995). Soil Amendments and Environmental Quality. CRC Press Inc.

Reeves, D.W. (1997). The list of soil organic matter in maintaining soil quality in continuous cropping system. Soil tillage Res., 43: 131-167.

Schnitzer, M. and Khan, S.U. (1978). Soil Organic Matter. Elsevier Scientific Publishing Company, Amsterdam, Oxford, New York. 


\section{Hamoud, H.S.}

Schnitzer, M. and Khan, S.V. (1972). Humic Substances in the Environment. Marcel Dekker, Inc., New York.

Shalaby, M.H.; Youssef, N.N. and Amer, A.M. (1989). Humic substances and its effect on availability of phosphorus in sandy soils irrigated by sewage effluent. Zagazig J. Agric. Res., 16(3): 385-402.

Snedecor, G.W. and Cochran W.G. (1967). Statistical Methods. $6^{\text {th }}$ ed. lowa Univ., USA.

Stevenson, F.J. (1982). Humus chemistry "Genesis composition and reaction". Wiley Inter. Science, New York, USA.

Stevenson, F.J. (1994). Humus chemistry genesis composition, reaction. Wiley, New York, 496 pp.

Strickland, T.C. and Sollins P. (1987). Improved method of separating light and heavy fraction organic material from soil. Soil Sci. Soc. Am. J. 51: 13901393.

Tan, K.H. (Ed.) (1993). Principles of Soil Chemistry. $2^{\text {nd }}$ Ed. Marcel Dekker Inc., New York, USA.

Theodorou, C. (1999). Nitrogen transformation in article size fractions from a second rotation in forest soil. Commun. Soil. Sci. Plant Anal. 21: 407413.

Wu, S. (2001). Stability and maturity evaluation of biosolids compost. Ph.D. Dissertation University of Florida. Gainesville, USA, 97 pp.

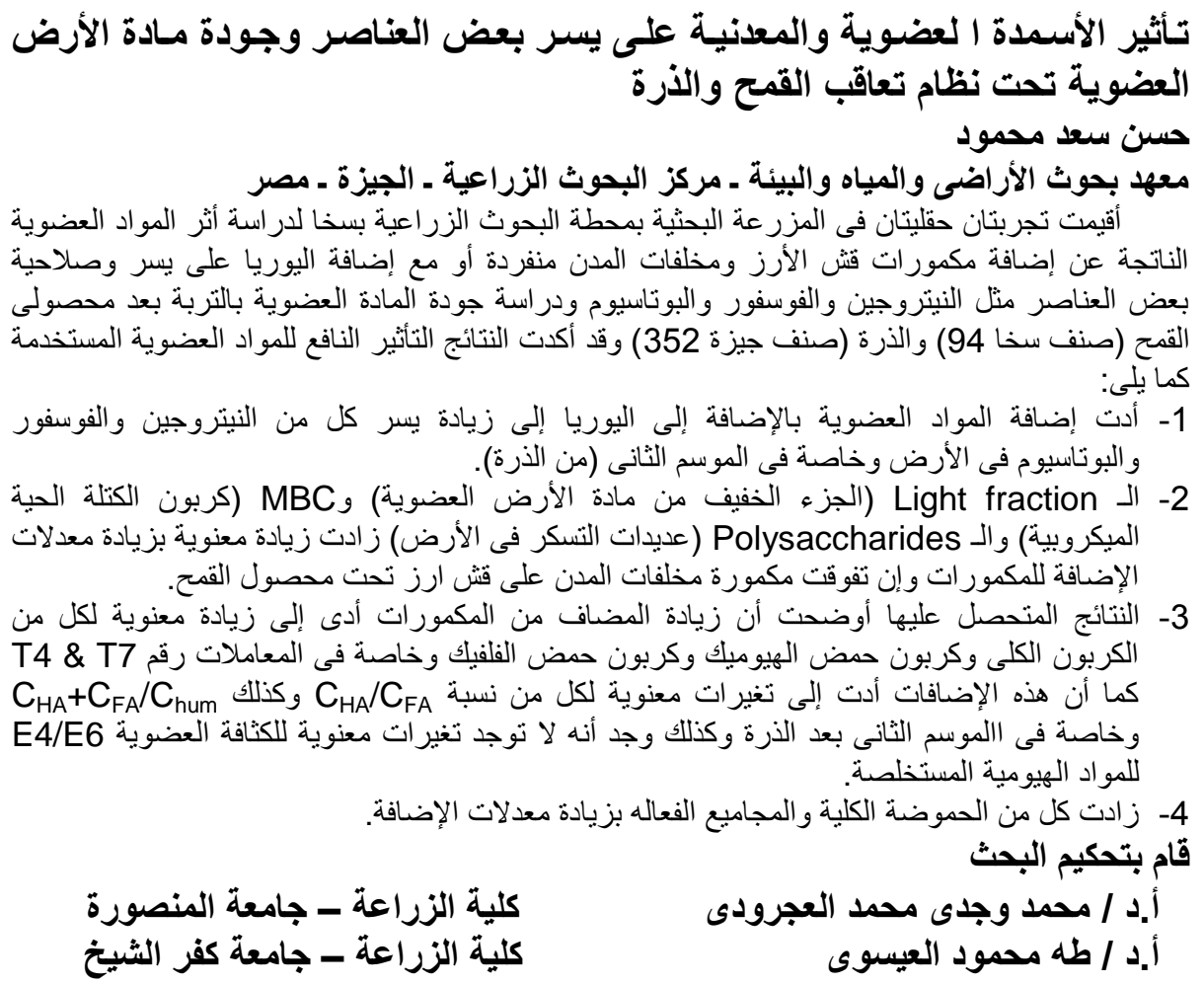


J. Soil Sciences and Agric. Engineering, Mansoura Univ., Vol.1 (5),May, 2010 
Table (5): Effect of compost and mineral fertilization on LF, MBC and polysaccharides of the tested soil after harvesting of wheat and corn.

\begin{tabular}{|c|c|c|c|c|c|c|c|c|}
\hline \multirow[t]{3}{*}{ Treat. } & \multicolumn{4}{|c|}{ Wheat } & \multicolumn{4}{|c|}{ Corn } \\
\hline & \multirow[t]{2}{*}{$\begin{array}{l}\text { L.F. } \text { mg kg }_{\text {soil }}^{-1} \\
\text { s. }\end{array}$} & \multirow[t]{2}{*}{ MBC $\mu \mathrm{g} \mathrm{g}^{-1}$ soil } & \multicolumn{2}{|c|}{$\begin{array}{l}\text { Polysaccharides } \mu \text { moles } \\
\text { glucose } \mathrm{g}^{-1} \text { soil }\end{array}$} & \multirow[t]{2}{*}{$\begin{array}{l}\text { L.F. } \mathbf{m g ~ k g}_{\text {soil }} \\
\text { k-1 }\end{array}$} & \multirow[t]{2}{*}{ MBC $\mu \mathrm{g} \mathrm{g}^{-1}$ soil } & \multicolumn{2}{|c|}{$\begin{array}{l}\text { Polysaccharides } \mu \text { moles } \\
\text { qlucose } \mathrm{q}^{-1} \text { soil }\end{array}$} \\
\hline & & & Total & Labile & & & Total & Labile \\
\hline$T_{1}$ & $5.83 f$ & $193.45 \mathrm{e}$ & $317.24 \mathrm{~d}$ & $283.59 \mathrm{c}$ & $5.76 \mathrm{~d}$ & $186.39 \mathrm{~d}$ & $312.31 \mathrm{~b}$ & $280.32 \mathrm{~cd}$ \\
\hline $\mathrm{T}_{2}$ & $6.44 f$ & $231.70 \mathrm{~d}$ & $374.20 \mathrm{c}$ & $257.89 \mathrm{c}$ & $6.12 \mathrm{~d}$ & $219.32 \mathrm{c}$ & $351.22 \mathrm{~b}$ & $249.37 d$ \\
\hline $\mathrm{T}_{3}$ & $16.66 \mathrm{~d}$ & $335.11 \mathrm{bc}$ & $437.24 \mathrm{ab}$ & $389.64 \mathrm{ab}$ & $14.89 \mathrm{c}$ & $307.91 \mathrm{~b}$ & $413.58 \mathrm{ab}$ & $358.39 \mathrm{ab}$ \\
\hline $\mathrm{T}_{4}$ & $18.47 \mathrm{bc}$ & $357.42 \mathrm{ab}$ & $458.23 \mathrm{a}$ & $392.23 \mathrm{ab}$ & $16.46 \mathrm{~b}$ & $316.77 \mathrm{ab}$ & $421.41 \mathrm{ab}$ & $\mathrm{u} 335.98 \mathrm{bc}$ \\
\hline $\mathrm{T}_{5}$ & $15.26 \mathrm{e}$ & $324.87 \mathrm{c}$ & $401.72 b c$ & $364.25 \mathrm{~b}$ & $14.19 \mathrm{c}$ & $309.11 \mathrm{~b}$ & $397.66 \mathrm{ab}$ & $3763.92 \mathrm{ab}$ \\
\hline $\mathrm{T}_{6}$ & $17.35 \mathrm{~cd}$ & $362.44 \mathrm{ab}$ & $453.78 \mathrm{a}$ & $374.24 \mathrm{ab}$ & $17.82 \mathrm{a}$ & $349.61 \mathrm{a}$ & $507.93 \mathrm{a}$ & $327.55 \mathrm{bc}$ \\
\hline $\mathrm{T}_{7}$ & $20.25 \mathrm{a}$ & $374.43 \mathrm{a}$ & $458.97 \mathrm{a}$ & $403.48 \mathrm{a}$ & $18.32 \mathrm{a}$ & $331.74 \mathrm{ab}$ & $414.93 \mathrm{ab}$ & $416.67 \mathrm{a}$ \\
\hline $\mathrm{T}_{8}$ & $19.67 \mathrm{bc}$ & $379.22 \mathrm{a}$ & $455.33 \mathrm{a}$ & $455.33 \mathrm{a}$ & $18.93 \mathrm{a}$ & $343.83 \mathrm{a}$ & $401.82 \mathrm{ab}$ & $379.53 \mathrm{ab}$ \\
\hline L.S.D. 5\% & 1.38 & 28.22 & 36.55 & 31.23 & 1.29 & 25.98 & 121.15 & 58.86 \\
\hline L.S.D. $1 \%$ & 1.89 & 38.89 & 50.36 & 43.02 & 1.78 & 35.79 & 166.91 & 81.09 \\
\hline
\end{tabular}

In the same column, means followed by the same letter are not significantly different at $5 \%$ level according to Duncan multiple range test $\mathrm{LF}=$ Light fraction

MBC = Microbial biomass carbon

Table (6):Effect of compost type and mineral nitrogen application on soil organic carbon fractions after harvesting of wheat and corn.

\begin{tabular}{|c|c|c|c|c|c|c|c|}
\hline \multirow{2}{*}{ Treat. } & OC\% & $\mathrm{C}_{\mathrm{HA}} \%$ & $\mathrm{C}_{\mathrm{FA}} \%$ & $\mathbf{C}_{\text {humin }} \%$ & $\mathrm{C}_{\mathrm{HA} /} / \mathbf{C}_{\mathrm{FA}}$ & $\left(\mathrm{C}_{\mathrm{HA}}+\mathrm{C}_{\mathrm{FA}}\right) / \mathrm{C}_{\text {humin }}$ & $E_{4} / E_{6}$ \\
\hline & \multicolumn{7}{|c|}{ Wheat } \\
\hline$T_{1}$ & $0.98 \mathrm{c}$ & $20.47 d$ & $16.37 \mathrm{~d}$ & $63.16 \mathrm{a}$ & $1.25 \mathrm{ab}$ & $0.58 \mathrm{e}$ & $3.66 \mathrm{a}$ \\
\hline$T_{2}$ & $1.07 \mathrm{c}$ & $23.26 \mathrm{c}$ & $16.80 \mathrm{~cd}$ & $59.94 \mathrm{a}$ & $1.38 \mathrm{~b}$ & $0.67 d$ & $3.68 \mathrm{a}$ \\
\hline $\mathrm{T}_{3}$ & $\begin{array}{l}1.41 \mathrm{a} \\
1.56 \mathrm{a}\end{array}$ & $\begin{array}{l}33.99 a \\
34.39 a\end{array}$ & 20.78 a & $45.23 \mathrm{c}$ & $1.64 \mathrm{ab}$ & $1.21 \mathrm{a}$ & $3.58 \mathrm{a}$ \\
\hline $\mathrm{T}_{4}$ & $\begin{array}{l}1.56 a \\
1.43 b\end{array}$ & $\begin{array}{l}34.39 a \\
29.78 b\end{array}$ & $\begin{array}{l}20.30 a \\
20.22 a\end{array}$ & $45.31 \mathrm{c}$ & $\begin{array}{r}1.69 a \\
1.47 a b\end{array}$ & $\begin{array}{l}1.21 \mathrm{a} \\
1.00 \mathrm{~b}\end{array}$ & $\begin{array}{l}3.45 a \\
3.51\end{array}$ \\
\hline $\mathrm{T}_{6}^{5}$ & $1.37 \mathrm{~b}$ & $28.37 \mathrm{~b}$ & $\begin{array}{l}19.08 \mathrm{ab} \\
19\end{array}$ & $\begin{array}{l}50.00 \mathrm{D} \\
52.55 \mathrm{~b}\end{array}$ & $1.49 \mathrm{ab}$ & $0.90 \mathrm{c}$ & $\begin{array}{l}3.51 \mathrm{a} \\
3.55 \mathrm{a} \\
\end{array}$ \\
\hline $\mathrm{T}_{7}^{\circ}$ & $1.44 \mathrm{~b}$ & $29.64 \mathrm{~b}$ & $18.30 \mathrm{bc}$ & $52.06 \mathrm{~b}$ & $1.62 \mathrm{ab}$ & $0.92 \mathrm{bc}$ & $3.39 \mathrm{a}$ \\
\hline $\mathrm{T}_{8}^{\prime}$ & $1.32 \mathrm{~b}$ & $27.41 \mathrm{~b}$ & $18.32 \mathrm{bc}$ & $54.27 \mathrm{~b}$ & $1.50 \mathrm{ab}$ & $0.84 \mathrm{c}$ & $3.44 \mathrm{a}$ \\
\hline L.S.D. 5\% & 0.10 & 2.49 & 1.63 & 4.38 & 0.25 & 0.08 & 0.30 \\
\hline \multirow[t]{2}{*}{ L.S.D. $1 \%$} & 0.15 & 3.43 & 2.25 & 6.4 & 0.34 & 0.11 & 0.42 \\
\hline & \multicolumn{7}{|c|}{ Corn } \\
\hline$T_{1}$ & $0.89 \mathrm{e}$ & $19.33 \mathrm{e}$ & $15.25 b$ & $65.42 \mathrm{a}$ & $1.27 \mathrm{c}$ & $0.53 \mathrm{e}$ & $3.67 \mathrm{a}$ \\
\hline $\mathrm{T}_{2}$ & $1.18 \mathrm{~d}$ & $22.13 d$ & $16.20 \mathrm{~b}$ & $61.67 \mathrm{a}$ & $1.37 \mathrm{c}$ & $0.62 \mathrm{de}$ & $3.61 \mathrm{a}$ \\
\hline $\mathrm{T}_{3}$ & $1.45 \mathrm{a}$ & $30.18 \mathrm{ab}$ & $19.37 a$ & $50.10 \mathrm{c}$ & $1.53 \mathrm{a}$ & $1.00 \mathrm{bc}$ & $3.50 \mathrm{a}$ \\
\hline $\mathrm{T}_{4}$ & $1.53 \mathrm{ab}$ & $31.22 \mathrm{a}$ & $20.61 \mathrm{a}$ & $48.07 \mathrm{c}$ & $1.50 \mathrm{ab}$ & $1.80 \mathrm{a}$ & $3.42 \mathrm{a}$ \\
\hline T5 & $1.40 \mathrm{C}$ & $29.17 \mathrm{ab}$ & $19.33 \mathrm{a}$ & $51.50 \mathrm{bc}$ & $1.51 \mathrm{a}$ & $0.95 \mathrm{bcd}$ & $3.49 \mathrm{a}$ \\
\hline $\mathrm{T}_{7}^{6}$ & $\begin{array}{l}1.31 \mathrm{c} \\
1.38 \mathrm{bc}\end{array}$ & $\begin{array}{l}28.09 \mathrm{D} \\
30.54 \mathrm{ab}\end{array}$ & $19.77 \mathrm{a}$ & $\begin{array}{l}51.61 \mathrm{bc} \\
50.02 \mathrm{c}\end{array}$ & $\begin{array}{l}1.38 \mathrm{bc} \\
152 \mathrm{a}\end{array}$ & $\begin{array}{l}1.27 \mathrm{~b} \\
1.00 \mathrm{bc}\end{array}$ & $\begin{array}{l}3.50 \mathrm{a} \\
3.35 \mathrm{a}\end{array}$ \\
\hline $\mathrm{T}_{8}^{\prime}$ & $1.28 \mathrm{c}$ & $25.32 \mathrm{c}$ & $19.42 \mathrm{a}$ & $55.26 \mathrm{~b}$ & $1.31 \mathrm{a}$ & $0.81 \mathrm{cde}$ & $3.49 \mathrm{a}$ \\
\hline L.S.D. 5\% & 0.11 & 2.39 & 1.68 & 4.72 & 0.13 & 0.34 & 0.30 \\
\hline L.S.D. $1 \%$ & 0.15 & 3.29 & 2.32 & 6.50 & 0.17 & 0.47 & 0.42 \\
\hline
\end{tabular}

In the same column, means followed by the same letter are not significantly different at $5 \%$ level according to Duncan multiple range test

$\mathrm{OC}=$ Organic carbon $\quad \mathrm{C}_{\mathrm{HA}}=$ Humic acid carbon $\quad \mathrm{C}_{\mathrm{FA}}=$ Fulvic acid carbon

OM = Organic matter $\quad C_{\text {humin }}=$ Humin carbon $\quad E_{4} / E_{6}=$ Optical density 
J. Soil Sciences and Agric. Engineering, Mansoura Univ., Vol.1 (5),May, 2010 